Fall 1979

\title{
Constitutionalizing Forfeiture Law-The German Example
}

James Maxeiner

University of Baltimore School of Law, jmaxeiner@ubalt.edu

Follow this and additional works at: http://scholarworks.law.ubalt.edu/all_fac

Part of the Criminal Law Commons, and the Criminal Procedure Commons

\section{Recommended Citation}

Constitutionalizing Forfeiture Law_The German Example, 27 Am. J. Comp. L. 635 (1979)

This Article is brought to you for free and open access by the Faculty Scholarship at ScholarWorks@University of Baltimore School of Law. It has been accepted for inclusion in All Faculty Scholarship by an authorized administrator of ScholarWorks@University of Baltimore School of Law. For more information, please contact snolan@ubalt.edu. 


\title{
Comments
}

\section{CONSTITUTIONALIZING FORFEITURE LAW-THE GERMAN EXAMPLE}

\author{
James R. Maxeiner*
}

In the United States a common legal consequence of the commission of crime is forfeiture of property used to violate the law. Confiscation of an automobile used to smuggle drugs is a typical example. In most cases the function of forfeiture is either to punish criminals or to prevent further use of the property in crime. Forfeiture statutes are closely connected with the criminal law and ought to be analysed with that branch of law, but in the United States forfeiture law has achieved an existence wholly apart from criminal law. That separate existence is attributable to an historical accident in the 19th century when forfeiture came to be thought an exclusively civil sanction necessarily imposed in an in rem action. ${ }^{1}$ This characterization focused attention on the property and tended to obscure the relation between the property forfeited and the criminal involvement of its owner. For the last half century the question whether government may permissibly take citizens' property in a forfeiture action has been determined by a single considerationwhether the property has been used in unlawful activity. ${ }^{2}$

This simplification of the question of forfeiture has caused many unjust confiscations. Owners guilty of only minor infractions have sometimes been subjected to disproportionate forfeitures. ${ }^{3}$ Wholly innocent owners have frequently lost their property when someone else, without their knowledge, used the property to commit crime. ${ }^{4}$

- James R. Maxeiner is Trial Attorney, Antitrust Division, U. S. Department of Justice. I would like to thank Professors G. Robert Blakey, Albin Eser, and George Fletcher for their helpful comments on earlier drafts of this article. The views expressed here are my own and not necessarily those of the Justice Department.

1. See generally Note, "Bane of American Forfeiture Law-Banished at Last?," 62 Cornell L. Rev. 768, 779-792 (1977).

2. See Calero-Toledo v. Pearson Yacht Leasing Co., 416 U.S. 663 (1974); J.W. Goldsmith Jr.-Grant Co. v. United States, 254 U.S. 505, 513 (1921).

3. See e.g., Commonwealth v. One 1970 Lincoln Auto., 212 Va. 597, 186 S.E.2d 279

(1972) (upholding forfeiture of $\$ 8700$ automobile for driving with a revoked license).

4. See e.g., United States v. One 1973 Buick Riviera Auto., 560 F.2d 897 (8th Cir. 1977). The owner is subject to strict as well as vicarious liability: unwitting illegal 
Again and again owners have unsuccessfully raised constitutional objections to confiscation of property without compensation. American courts have most frequently replied with an analogy to the medieval law of deodand, in which they find the origin of modern enactments. ${ }^{5}$ The deodand was the instrument of a man's death; it was forfeit as "guilty property" regardless of the owner's culpability. ${ }^{6}$ This fiction has allowed most American courts to avoid analysis of forfeiture. It is probably not the principal reason our courts have resisted constitutional challenges; rather, they have allowed far reaching confiscations because of the remedial purposes seen to be served by some forfeitures: the principal idea is that taking the property prevents its future illegal use. ${ }^{7}$ American courts have tended to neglect the punitive side of forfeiture, since punishment seems inconsistent with an in rem action. ${ }^{8}$

In the last fifteen years some American courts have subjected modern forfeiture statutes to closer scrutiny. Five federal courts and three state supreme courts have held forfeiture statutes unconstitutional on substantive grounds. ${ }^{9}$ Four other state supreme courts have avoided constitutional attacks by narrow statutory construction. ${ }^{10}$ In 1974 the United States Supreme Court slowed the trend against forfeiture in the federal courts by reversing a three judge district court that had found one statute unconstitutional. ${ }^{11}$

use incurs forfeiture. Combining the two forms of liability means that an automobile can be conflscated where neither the owner nor the driver knows of the unlawful use. See e.g., United States v. One 1957 Oldsmobile Auto., 256 F.2d 931 (5th Cir. 1957) (ordering forfeiture where passenger carried 1/30th ounce marijuana without driver's knowledge).

5. "It is the property which is proceeded against, and, by resort to a legal fiction, held guilty and condemned as though it were conscious instead of inanimate and insentient." Various Items of Personal Property v. United States, 282 U.S. 577, 581 (1931). See Calero-Toledo v. Pearson Yacht Leasing Co., 416 U.S. at 682; J.W. Goldsmith, Jr.-Grant Co. v. United States, 254 U.S. at 510-11; United States v. One Buick Skylark, 453 F. Supp. 639, 643 (D. Colo. 1978).

6. See Note, supra n. 1 at 771-72.

7. See e.g., Calero-Toledo v. Pearson Yacht Leasing Co., 416 U.S. at 687; Commissioner's Note to Uniform Controlled Substances Act $\$ 505$.

8. See e.g., United States v. One 1967 Ford Mustang, 457 F.2d 931 (9th Cir.), cert. denied 409 U.S. 850 (1972).

9. McKeehan v. United States, 438 F.2d 739 (6th Cir. 1971); Pearson Yacht Leasing Co. v. Massa, 363 F. Supp. 1337 (D.P.R. 1973), rev'd sub nom. Calero-Toledo v. Pearson Yacht Leasing Co., 416 U.S. 663 (1974); United States v. One 1971 Ford Truck, 346 F. Supp. 613 (C.D. Cal. 1972); Suhomlin v. United States, 345 F. Supp. 650 (D. Md. 1972); United States v. One Bally Sun Valley Pinball Machine, 340 F. Supp. 307 (W.D. La. 1972); In re One 1965 Mustang, 105 Ariz. 293, 463 P.2d 827 (1970); 1957 Chevrolet v. Division of Narcotic Control, 27 Ill.2d 429, 189 N.E.2d 347 (1963); State v. 1971 Green GMC Van, 354 So.2d 479 (La. 1977). Several other state courts have struck down forfeiture statutes on procedural grounds. See People v. Campbell, 39 Mich. App. 443, 198 N.W.2d 7 (1972); State v. Miller, 248 N.W.2d 377 (S. Dak. 1976); Rumfolo v. State, 535 S.W.2d 16 (Tex. Civ. App. 1976), rev'd 545 S.W.2d 752 (Tex. 1977); State v. One 1972 Mercury Capri, 85 Wash.2d 620, 537 P.2d 763 (1975).

10. One Cocktail Glass v. State, 565 P.2d 1265 (Alaska 1977); Griffis v. State, 356 So.2d 297 (Fla. 1978). State v. One 1972 Grand Prix 2-Door Hardtop, 242 N.W.2d 660 (S. Dak. 1976); State v. One Porsche 2-Door, 526 P.2d 917 (Utah 1974).

11. Calero-Toledo v. Pearson Yacht Leasing Co., 416 U.S. 663 (1974). 
The Court nevertheless encouraged a limited reform of the law by recognizing that "it would be difficult to reject the constitutional claim of an owner ... [ [who] had done all that could reasonably be expected to prevent the proscribed use of his property." 12 In the state courts the trend against forfeiture has continued. ${ }^{13}$ Congress has also created a need to reconsider forfeiture law. In 1972 it amended the Federal Rules of Criminal Procedure to require that "criminal forfeitures" (as contrasted to "civil forfeitures") be imposed in criminal prosecution of the owner. ${ }^{14}$ Congress did not specify what constitutes a criminal forfeiture. Taking these events of recent years together, it is clear that American courts must now fully reassess forfeiture law.

With few precedents to guide them, American courts will of necessity move slowly in their reconsideration. That reconsideration could be expedited if a systematic exposition of forfeiture and constitutional principles could be found. The dearth of American analysis suggests considering the approaches of other legal systems.

In Germany, legal scholarship in the field of forfeiture is extensive. Germany has long had forfeiture provisions comparable to our own. With the adoption of the American-inspired West German constitution, German scholars, judges, and legislators acted to modify their law, including its forfeiture provisions, to bring it into accord with strengthened constitutional guarantees. In the two decades between 1949 and 1968 German lawyers have dealt at length with the same problems now facing American forfeiture law. ${ }^{15}$

\section{German Forfeiture Statutes}

$\S 40$ of the German Criminal Code of 1871 mandated that "[o] bjects produced by a deliberate felony or misdemeanor, or used or intended for committing a deliberate felony or misdemeanor, may be forfeited if they belong to the principal perpetrator or an accomplice."16 $\$ 40$ remained essentially unchanged until superseded in

12. Id. at 689 . For developments of this theme, see United States v. One 1972 Chevrolet Blazer, 563 F.2d 1386 (9th Cir. 1977); Wiren v. Eide, 542 F.2d 757 (9th Cir. 1976); United States v. One 1976 Lincoln Mark IV, 462 F. Supp. 1383 (W.D. Pa. 1979); United States v. One 1974 Mercury Cougar XR 9, 397 F. Supp. 1325 (C.D. Cal. 1975).

13. See the cases decided after 1974 cited in $n .9 \& 10$ supra. Other state courts relying on Calero-Toledo have rejected constitutional challenges. See State v. 36 Pinball Machines, 565 P.2d 236 (Kan. 1977); State v. One 1968 Volkswagen, 198 Neb. 45, 251 N.W.2d 666 (1977).

14. Fed. R. Crim. P. 7(c) (2), 31(c), 32(b)(2), 54(b) (5). See Advisory Committee's Comments to the 1972 Amendments to the Federal Rules of Criminal Procedure, 56 F.R.D. 143, 180 (1972); Note, supra n. 1 at 792-93.

15. Throughout this article references to Germany after 1948 are to the Federal Republic (West Germany). This article makes no attempt to examine forfeiture law other than in Germany and the United States. For a limited comparison of forfeiture in civil law countries, see Scharff, "Die Einziehung," in Materialien zur Strafrechtsreform vol. 2, Allgemeiner Teil at 253-59 (1954). Scharff suggests that forfeiture has not been systematically considered elsewhere; in common law countries, see Comment, "Forfeiture remission, a comparative study," 8 Calif. W. Int. L. Rev. 586 (1978).

16. Reichsstrafgesetzbuch [RStGB] $\$ 40$ (1871) [all translations are mine unless 
1968. ${ }^{17}$ While $\S 40$ placed forfeiture in the discretion of the trial judge, other statutes required the judge to order forfeiture in all cases, even though in some instances the property belonged to an innocent third party. Following the adoption of the Basic Law (the West German Constitution) in 1949, some of the broader-reaching forfeiture statutes were criticized as inconsistent with the Basic Law. ${ }^{18}$ In 1951 the Federal Supreme Court held in effect that earlier forfeiture statutes could be enforced only in conformity with the constitution. ${ }^{19}$

As the Federal Supreme Court began to reassess forfeiture law, German lawyers began consideration of a new criminal code to replace the 1871 code. Various proposals culminated in the draft presented to the West German parliament in 1962. Four years later a group of liberal criminal law professors published an alternative draft of the general part of the code. Eventually compromises were reached and in 1975 a new criminal code became fully effective. ${ }^{20}$

One goal of the drafters of the new criminal code was to bring German forfeiture statutes into conformity with the Basic Law, ${ }^{21}$ and accordingly they made changes throughout German forfeiture law. ${ }^{22}$ The reform culminated in the Regulatory Offenses Act of 1968 and the accompanying introductory legislation.23 That act includes a new scheme of forfeiture law formulated on a constitutional ba-

otherwise noted]. Gegenstande when it appears in the 1871 code is translated as "objects," but as "property" when it appears in the new forfeiture legislation. See n. 14142 and accompanying text infra. For translations of the 1871 Criminal Code, see Drage, The Criminal Code of the German Empire (1885); Gsirski \& James, The Statutory Criminal Law of Germany (1947); Mueller \& Buergenthal, German Penal Code (Am. Series of Foreign Penal Codes vol. 4, 1961). The predecessors of $\S 40$ go back to the 1805 Prussian Criminal Code. See Judgment of 5 December 1956, 10 Entscheidungen des Bundesgerichtshofs in Strafsachen [BGHSt] 28, 30.

17. Strafgesetzbuch [StGB] $\S 40$ (1953); superseded by Act of 24 May 1968, 1968 BGB1.I 503; StGB $\S 40$ (1968); StGB $§ 74$ (1975) [hereafter citations to the StGB without date are to the 1975 code now in force].

18. See e.g., Hartung, "Die Einziehung nach dem § 414 RAbgO," 1949 Neue Juristische Wochenschrift [NJW] 765.

19. Judgment of 9 October 1951, 1 BGHSt 351

20. See generally, Eser, "Germany [Politics of Criminal Law Reform]," $21 \mathrm{Am}$. J. Comp. L. 245 (1973); "Symposium, The New German Penal Code," 24 Am. J. Comp. L. 589-778 (1976).

21. Germany, Bundesministerium der Justiz, Entwurf des Allgemeinen Teils eines Strafgesetzbuchs nach den Beschlussen der Grossen Strafrechtskommission in Erster Lesung (abgeschlossen im Dezember 1956) mit Begrandung 109, 112-13, 115 (1958). The draft will be cited as Entwurf 1956, if to the proposed code; as Entwurf 1956 mit Begrindung, if to the accompanying commentary. The $1960 \mathrm{draft}$, Entwurf eines Strafgesetzbuches 1960, and the 1962 draft, Entwurf eines Strafgesetzbuches 1962, are cited in the same fashion. The $1962 \mathrm{draft}$ has been translated, see Ross, German Draft Penal Code E 1962 (Am. Series of Foreign Penal Codes vol. 11, 1966).

22. The first changes were made in the Duty and Impost Order. See Abgabenordnung [AO] §§ 414-15 (1961).

23. Gesetz uber Ordnungswidrigkeiten [OWiG] of 24 May 1968, 1968 BGB1.I 481; Einfuhrungsgesetz zum Ordnungswidrigkeiten [EGOWiG] of 24 May 1968, 1968 BGB1.I 503. See Eser, supra n. 20 at 250-51. 
sis. ${ }^{24}$ The introductory legislation made analogous changes in the Criminal Code of 1871 and additional alterations in the Code of Criminal Procedure. ${ }^{25}$ The 1968 amendments to the old criminal code were incorporated with only minor changes in the new Criminal Code of $1975 .{ }^{26}$

\section{The Nature of Forfeiture-Punishment or Preventive MEASURE?}

Since the enactment of $\S 40$ in 1871 , German scholarship has begun consideration of forfeiture by looking to its legal nature. Early commentators argued that all forfeitures were alike; some saw forfeitures as exclusively punishments, others considered them to be exclusively preventive measures. ${ }^{27}$ By about the turn of the century however, both earlier views were rejected. Courts and commentators then recognized that there were two different types of forfeiture, one type serving as punishment, the other as a preventive measure. ${ }^{28}$ This view of forfeiture as "ambivalent" has been almost universally held in German law ever since. ${ }^{29}$ Disagreement has centered on how one distinguishes the punitive forfeiture from the preventive.

The Reich Supreme Court applied a simple test. If the statute allowed the forfeiture only of property owned by a principal or an accomplice, then the forfeiture was punitive. If the forfeiture extended to property generally, regardless of ownership, it was preventive. ${ }^{30}$ In the early years of the Federal Republic courts and

24. OWiG $\S \S 22-29,87$.

25. StGB $\S \S 40-42$ (1968); Strafprozessordnung [StPO] $\S \S 430-42$.

26. StGB $\$ \S 74-76 \mathrm{a}$. All citations to the 1968 reform will be to the code section of the legislation in force since 1975, and not to the section numbers used under the old StGB and the new OWiG from 1968 to 1974 .

27. See Dietrichs, "Die Strafrechtliche Einziehung und die Eigentumsgarantie des Grundgesetzes" 3 (Dissertation Hamburg 1964); Eser, Die Strafrechtlichen Sanktionen gegen das Eigentum 62-67 (1968) [hereafter Eser].

28. Judgment of 18 June 1912, 46 Entscheidungen des Reichsgerichts in Strafsachen [RGSt] 379. Cf. Dochow, "Einziehung" in 1 Holtzendorff, Rechtslexikon 661 (3d ed. 1880). See Dietrichs, supra n. 27 at 3-4; Eser at 67-70, 73-74. At almost the same time as Germany came to generally recognize the dual nature of forfeiture, America, which previously had recognized a similar punitive/regulatory distinction, began to abandon it. See Note, supra n, 1 at 783-91.

29. See Dreher, Strafgesetzbuch mit Nebengesetzen und Verordnungen $\S 74$ at 371 (36th ed. 1976) [hereafter Dreher]; Eser at 72-73; Gobler, Gesetz über Ordnungswidrigkeiten 135.37 (5th ed. 1977) [hereafter Gobler, OWiG]; Lackner, Strafgesetzbuch mit Erlauterungen $\$ 74$ at 342 (11th ed. 1977) [hereafter Lackner]; Kleinknecht, Strafprozessordnung 887 (33d ed. 1977) [hereafter Kleinknecht, StPO]; Schonke \& Schroder, Strafgesetzbuch Kommentar 790-91 (19th ed. 1977) (this section revised by Eser) [hereafter Schonke-Schroder-Eser]; Schonke \& Schroder, Strafgesetzbuch Kommentar $\S 40$ at 184-85 (12th ed. 1965) [hereafter Schonke-Schroder (12th ed.)]; Schwarz \& Dreher, Strafgesetzbuch $\$ 40$ at 122-23 (29th ed. 1967) [hereafter Schwarz-Dreher]; 1 Strafgesetzbuch Leipziger Kommentar \$ 40 margin no. 1 (this section by Schafer) (9th ed. 1970-74) [hereafter Schafer LK].

30. Judgment of 18 June 1912, 46 RGSt 131; Judgment of 29 January 1929, 63 RGSt 379. See Dietrichs, supra n. 27 at 4; Eser at 70-75. 
commentators largely adhered to this position. ${ }^{31}$ Nevertheless, for constitutional purposes, the Federal Supreme Court chose to look to the underlying nature of the sanction. The Court admitted the punitive nature of certain third-party forfeitures and thereby recognized a new classification, the so-called "punishment-like" forfeiture. ${ }^{32}$

Since the adoption of the Basic Law in 1949 the characterization of the legal nature of forfeiture has assumed increased importance. The classification as punitive or preventive is a fundamental first step in constitutional analysis. A given forfeiture must satisfy the constitutional requirements of one classification or the other. A forfeiture which is valid neither as a punishment nor as a measure to protect society is unconstitutional. Greater emphasis on the punitive/preventive classification has resulted in courts and commentators reformulating the distinguishing test. The "essence and purpose" of the sanction are decisive. If the statute looks to the actor, if it is directed toward atonement for past wrong, the forfeiture is punitive, or, at least "punishment-like." If the statute looks to the property without regard to the guilt of the actor, if it contemplates resisting a danger to the community, then it is preventive. ${ }^{33}$ Therefore punitive forfeiture is subjective and past-directed, whereas preventive forfeiture is objective and future-directed. Actor-related criteria are characteristic of punitive forfeitures, while property-related criteria are typical of preventive forfeitures. ${ }^{34}$ Despite the lesser rigidity of more recent law, Professors Eser and Schroder have called for a broader, yet more individualized inquiry. They would look to all the circumstances, not just to legislative purpose. Moreover, they would make the characterization with respect to each individual case, rather than for all cases under one statute. ${ }^{35}$ Both the 1968 reform act and the 1975 code leave open the question of how to characterize individual forfeitures. ${ }^{36}$

\section{Conforming the Substantive Law to the Constitution}

\section{A. Actor-Directed Punitive Forfeiture}

\section{The Guilt Principle}

It is a fundamental principle of modern German law that pun-

31. Judgment of 31 March 1954, 6 BGHSt 62; Niethammer, Strafgesetzbuch $\$ 40$ at 32-33 (1954); Schwarz-Dreher $\S 40$ at 122-23. See Dietrichs, supra n. 27 at 4-6; Eser at 75-76.

32. Judgment of 9 October 1951, 1 BGHSt 351. Gilsdorf notes that in any case for constitutional purposes the determination of the nature of the sanction can't be left to legislative decision alone. Gilsdorf, "Die verfassungsrechtlichen Schranken der Einziehung," 1958 Juristenzeitung [JZ] 641, 642 [hereafter Gilsdorf, $1958 \mathrm{JZ}$ ]. For the "punishment-like" forfeiture, see n. 63-93 and accompanying text infra.

33. Judgment of 16 July 1965, 20 BGHSt 253 ; Eser at 90.

34. Eser at 91; Schonke-Schroder-Eser at 791. See also Lackner $\$ 74$ at 342; Schafer LK § 40 margin nos. 4-8.

35. Eser at 76-77, 92-97; Schonke-Schroder-Eser at 791; Schonke-Schröder $\$ 40$ at 185 (12th ed.). Cf. Dietrichs, supra n. 27 at 20-28.

36. Entwurf 1956 mit Begrundung at 109; Schonke-Schroder-Eser at 790. 
ishment may be imposed only for personal blameworthiness. ${ }^{37}$ This "principle of guilt" (Schuldprinzip) is of constitutional rank. ${ }^{38}$ As applied to forfeiture statutes, the principle requires blameworthiness to support a punitive or "punishment-like" forfeiture. In the absence of guilty conduct, forfeiture is contrary to the guilt principle and cannot be justified except as a purely preventive measure. ${ }^{39}$ Yet many statutes predating the 1949 constitution allowed or required forfeiture where the owner was not blameworthy and where the circumstances did not justify a preventive measure. In 1951 the Federal Supreme Court held that the effect of the Basic Law on these older statutes was to obligate the trial judge not to order a forfeiture in violation of the guilt principle. ${ }^{40}$ Application of the guilt principle to German statutes has precluded forfeitures that are commonplace in the United States. For example, in Germany a punitive forfeiture cannot be ordered if the guilty actor has transferred his property to a bona fide purchaser. ${ }^{41}$ In America, not only is such a "relation back" possible, but our courts have construed it as characteristic of all forfeiture statutes. ${ }^{42}$ Generally, in German law, an owner not subject to punishment in his person cannot be subject to punishment in his property. Thus a punitive forfeiture will not be permissible if the owner is dead, insane, or otherwise legally not subject to prosecution. ${ }^{43}$ The 1968 reform act largely codified these results.

\section{The Property Guarantee}

It is undisputed that a forfeiture imposed as punishment,

37. Hamann, Grundgesetz und Strafgesetzgebung 17 (1963); Kaufmann, Das Schuldprinzip 15-20 (1961); Muller-Dietz, Grenzen des Schuldgedankens im Strafrecht 29 (1967).

38. Judgment of 18 March 1952, 2 BGHSt 194; Gilsdorf, $1958 \mathrm{JZ}$ at 686 . The guilt principle is usually taken to originate in the guarantee of human dignity ("Menschenwurde") of Art. 1 || 1 of the Basic Law. See Maunz \& Durig, Grundgesetz Kommentar at Art. 1 margin no. 32 (supplemented through 1976). Cf. Kaufmann, supra $n$. 37 at 116-211. For the place of the guilt principle in the Criminal Code of 1975, see Hermann, "Sanctions: German Law and Theory," $24 \mathrm{Am}$. J. Comp. L. 719-21 (1976).

39. Schonke-Schroder $\S 40$ at 185 (12th ed.).

40. Judgment of 9 October 1951, 1 BGHSt 351, 353-54; Judgment of 16 June 1958, 27 Entscheidungen des Bundesgerichtshofs in Zivil Sachen [BGHZ] 69, 71-72. In certain circumstances such a forfeiture might be permissible if accompanied by provision for full compensation of the innocent owner. Id.

41. This was a statutory requirement of the old law. Schwarz-Dreher $\$ 40$ at 124 . The 1956 draft proposal would have allowed this "relation back," but would have compensated the bona fide purchaser. Entwurf $1956 \$ \$ 120 \mathrm{cl}$. 1, 125 ๆ 1 . This possibility was dropped in later drafts and as enacted, probably as pointless. Entwurf $1962 \S 113$; StGB § 74. As enacted, relation back is possible only if the subsequent taker is not bona fide. StGB \$ 74a cl. 2. See Eser at 218; Stree, Deliktsfolgen und Grundgesetz 11516 (1960).

42. Florida Dealers \& Growers Bank v. United States, 279 F.2d 673, 676 (5th Cir. 1960). See Note, supra n. 1 at 773 n. 37,780 n. 74.

43. Gilsdorf, $1958 \mathrm{JZ}$ at 688 ; StGB \& 76a; Schronke-Schroder-Eser \& 76a at 834; Schönke-Schroder $\S 42$ at 195 (12th ed.). Cf. Schwarz-Dreher $\S 40$ at 124 (pre-War law contra). 
though uncompensated, does not violate constitutional protections of property. ${ }^{44}$ Art. 14 of the Basic Law guarantees the right of property: property may not be taken, except for the public good and by a law providing for appropriate compensation. ${ }^{45}$ Though it is agreed that forfeiture may be imposed as punishment without providing compensation, there is no general agreement as to the exact theoretical source of this constitutional exception. ${ }^{46}$ The Federal Supreme Court has adopted a theory that the greater includes the lesser, that is, if the state may punish the guilty actor in his personal freedom, it may also punish him in his property ${ }^{47}$

\section{The Proportionality Principle}

German forfeitures must also conform to proportionality principles. The proportionality principle (Grundsatz der verhaltnismässigkeit) is a natural corollary to the guilt principle. Where the guilt principle demands blameworthiness as a necessary prerequisite to punishment, the proportionality principle requires that punishment not be disproportionate to blameworthiness (Schuld). ${ }^{48}$ Recognition of the constitutional rank of the proportionality principle in the early 1950 s had a special effect on earlier German statutes that had placed forfeiture outside the trial judge's discretion and required forfeiture in all instances. The Federal Supreme Court held that the proportionality principle requires the trial judge to examine the spe-

44. Judgment of 16 June 1958, 27 BGHZ 382, 384; Dietrichs, supra n. 27 at 29-30; Eser at 150-73.

45. Art. 14 reads in pertinent part:

(1) Property and the right of inheritance are guaranteed. Their content and limits shall be determined by the laws.

(2) Property imposes duties. Its use should also serve the public weal.

(3) Expropriation shall be permitted only in the public weal. It may be effected only by or pursuant to a law which shall provide for the nature and extent of compensation. Such compensation shall be determined by establishing an equitable balance between the public interest and the interest of those affected.

Grundgesetz [GG] Art. 14, translation from Germany, Press \& Information Office, $B a-$ sic Law for the Federal Republic of Germany 12 (1971).

46. Some see the property as placed outside constitutional protection by virtue of an unwritten constitutional provision. See Dietrichs, supra n. 27 at 29; Eser at 150-55; Stree, supra n. 41 at 87 . Others contend that punitive forfeiture is an expropriation within the meaning of Art. 14, but one that does not require compensation. See Eser at 155-56; Stree, supra n. 41 at 88-90. Finally, many would find support for the sanction in one of the two clauses in Art. 14 limiting the right of property, either Art. 14 \ 1 cl. 2 or Art. 14 || 2. See Dietrichs, supra n. 27 at 30; Eser at 166-73; Stree, supra n. 41 at 8590.

47. Judgment of 16 June 1958, 27 BGHZ 382, 384. See Kroner, "Die Einziehung und Art. 14 GG," 1959 NJW 81, 82 [hereafter Kroner, 1959 NJW]; Stree, supra n. 41 at 87-88.

48. The Bavarian Constitutional Court had already recognized the constitutional rank of the proportionality principle and its applicability to forfeiture in a judgment of 28 July 1950 . Within a few years recognition was general. See Dietrichs, supra n. 27 at 31-34; Eser at 352-53; Maunz \& Dürig, supra n. 38 at Art. 1 margin no. 32; SchonkeSchroder-Eser § 74b at 752-53; Silving, "Discussion of Sanctions," $24 \mathrm{Am}$. J. Comp. L. 737, 741-46 (1976). 
cific situation before him for the degree of blameworthiness of the owner and for the harshness of the forfeiture. If the actor's guilt is slight and the severity of the forfeiture great, the judge must deny the forfeiture, notwithstanding mandatory language in the statute. 49 American forfeitures, on the other hand, need not conform to proportionality principles, even though several state constitutions require proportionality in punishment and the federal constitution prohibits excessive fines. ${ }^{50}$ American courts, when faced with a challenge that a forfeiture is excessive, deny that forfeiture is a punishment, and thus avoid the question of proportionality altogether. ${ }^{51}$ In German law the proportionality principle was so widely accepted as a constitutional requirement, that the 1962 draft proposal for the new criminal code omitted any specific forfeiture proportionality principle as unnecessary. ${ }^{52}$ As for mandatory forfeiture, the constitutional requirement remains the only limitation. ${ }^{53}$ But in the case of forfeiture placed in the discretion of the trial judge, the 1968 reform act adds the further limitation that the judge shall not order a punitive or "punishment-like" forfeiture "if it would stand out of proportion to the consequences of the [illegal] deed committed and to the blame [worthiness of the person subjected to it]."54 Thus whether the forfeiture is mandatory or discretionary makes a difference in the standard applied.55 Since the overwhelming trend of new enactments is to place forfeiture in the discretion of the judge, ${ }^{56}$ the more restrictive standard will increasingly be the one applicable.

Application of the proportionality principle raises a number of questions. What makes a forfeiture excessive and therefore constitutionally forbidden? It is difficult to state more than the general constitutional requirement. Schroder considered a forfeiture to be constitutionally forbidden "if the iniquity of the deed and the actor's blameworthiness are so small, that the deprivation of the property . . . would mean a disproportionate hardship." 57 The statutory stan-

49. Judgment of 29 May 1970, 23 BGHSt 267, 269; Judgment of 17 October 1961, 16 BGHSt 282, 290; Dietrichs, supra n. 27 at 38; Schonke-Schroder-Eser $\$ 74 \mathrm{~b}$ at 817-18.

50. See e.g., Ill. Const. art. I, § 11; Ind. Const. art 1, § 16; Me. Const. art. I, § 9; Neb. Const. art. I, § 15; N.H. Const. art. I, § 18; Ore. Const. art. I, § 16; R.I. Const. art. I, § 8; W. Va. Const. art. III, \& 5 .

51. Contrast Commonwealth v. One 1970 Lincoln Automobile, 212 Va. 597, 186 S.E.2d 279 (1972) (upholding forfeiture of $\$ 8700$ automobile for driving with a revoked license) with Hoffmann-Walldorf, "Kann ein Kraftfahrzeug wenn der Fahrer keinen Fuhrerschein besitzt, eingezogen werden?," 1954 NJW 1147 (discussion of German case holding automobile not forfeit for driving without a license).

52. Eser at 353 n. 19.

53. Schonke-Schroder-Eser $\S 74 b$ at 817.

54. StGB \& 74b II 1 .

55. Judgment of 29 May 1970, 23 BGHSt 267, 269-70.

56. Entwurf 1956 mit Begrindung at 109.

57. Schonke-Schroder $\S 40$ at 187 (12th ed.). In practice, the constitutional requirement has meant that a youth's short wave radio could not be forfeit for occasional transmission of music. Judgment of 15 December 1966, Bayerisches Oberstes Landesgericht in $1967 \mathrm{NJW} 586$. Also, that an automobile could not be forfeit for the 
dard of relationship of sanction to blameworthiness is even more difficult to state precisely. In general, the severity of the forfeiture must be considered in relation to the value of the object forfeit. ${ }^{58}$ The problem is complicated by the usual nature of forfeiture as an all-or-nothing sanction. Taking the entire property may be too severe, while taking nothing may be too lenient. ${ }^{59}$ The 1968 reform act allows an intermediate, or partial, forfeiture where possible. ${ }^{60} \mathrm{~A}$ solution may be found in what appears to be a growing consensus that the punitive forfeiture must be considered as a part of the overall punishment.61 Thus, if the forfeiture would otherwise be too severe, it could be made permissible by an appropriate reduction in the primary sentence.

\section{B. Third-Party Directed "Punishment-like" Forfeiture}

The so-called "punishment-like" (strafähnlich) forfeiture arises when an owner, not himself a principal or an accessory to crime, is nevertheless made to suffer forfeiture of property for some degree of personal fault in allowing the property to be used illegally. The third party has not himself committed a crime; he cannot be sanctioned other than by the "punishment-like" forfeiture. Where the third party forfeiture proceeds on grounds of prevention of imminent danger, it is not "punishment-like."

The development of "punishment-like" forfeiture is a consequence of the application of constitutional guarantees to the broad-reaching third-party forfeitures that predated the Basic Law. Before 1949 many German statutes directed forfeitures without regard to the owner's guilt or danger to the public. A forfeiture of nondangerous property belonging to an innocent third party often resulted under these statutes because of some illegal use made of the property by another. The Reich Supreme Court and the earlier commentators sought to explain these forfeitures on various grounds. Sometimes the concept of preventive forfeiture was stretched to in-

owner's smuggling 600 cigarettes. Judgment of 13 October 1961, Oberlandesgericht [OLG] Hamm, in 1962 NJW 828. See Eser at 356; Kuhn, Abgabenordnung $\$ 414$ at 508 (8th ed. 1966) [hereafter Kuhn, AO] (giving example of unconstitutional excess as forfeiting automobile for smuggling one bottle of cognac).

In America, there once was a simple rule that there would be no forfeiture for a trivial infraction. Phile qui tam v. The Anna, 1 Dall. (1 U.S.) 197, 206 (C.P. Phila. County 1787). The rule's English counterpart dated back to the statute, $38 \mathrm{Edw} .3$, c. 8 (1363). Neither was strictly a proportionality rule. Today the smallness of the quantity of illegal goods is irrelevant, even where the owner is innocent. See United States v. One 1975 Mercedes 280S, 590 F.2d 196 (6th Cir. 1978). See also Note, supra n. 1 at 775 n. 44.

58. Dietrichs makes the point that it is not enough to say a vehicle used in illegal hunting may be validly forfeit. The forfeiture might not be excessive if the vehicle is a bicycle, but would be if the vehicle were a Mercedes. Dietrichs, supra $n .27$ at 35.

59. See Eser at 356.

60. StGB \& $74 b$ ๆ 3 .

61. Dietrichs, supra n. 27 at $36-38$; Dreher $\$ 74 \mathrm{~b}$ at 374 ; Eser at 356 (noting developing consensus and Schroder's change of attitude). 
clude these third-party forfeitures. ${ }^{62}$ Other times it was said that the owner stood in a position of guarantor with respect to his property: if the owner failed to prevent the illegal use of his property, it could justly be forfeit. ${ }^{63}$ Finally, a related theory held the property itself responsible for whatever illegal use was made of it. ${ }^{64}$ With the adoption of the Basic Law in 1949, these earlier forfeiture statutes became subject to the guilt principle and to the strengthened property guarantees of Art. 14. Applying these principles, the Federal Supreme Court in 1951 rejected the old theories that had once supported the non-preventive third-party forfeitures. ${ }^{65}$ It held that "to permit the uninvolved property owner to be held liable for the guilt of the principal or of an accessory is . . on grounds of justice and equity only justifiable, if the facts of the case contain a particular ground of justification for such a measure."66 The Court held however that it was not necessary that the third party be guilty of a crime. An appropriate legal justification was either a preventive measure or "if the uninvolved property owner could have recognized with the exercise of requisite and justly expected care, that the principal perpetrator or an accessory would use or could have used the property in the commission of the [illegal] act. . .."67 Thus arose the "punishment-like" third-party forfeiture, a criminal sanction imposed for a degree of blameworthiness, yet absent a crime by the owner.

\section{1. "Punishment-like" Forfeiture and the Property Guarantee}

"Punishment-like" forfeiture can avoid the constitutional property guarantee because the misuse of property places it outside the terms of that guarantee. ${ }^{68}$ Exactly what is sufficient misuse to overcome the property guarantee has been much discussed. That the property was used in a crime will not in itself suffice. As Eser notes,

62. Judgment of 7 April 1933, 67 RGSt 215; see Judgment of 9 October 1951, 1 BGHSt 351, 353.

63. Known as Garantenhaftung. See Eser at 78-80; Gilsdorf, $1958 \mathrm{JZ}$ at 686.

64. Judgment of 11 November 1935, 69 RGSt 385, 389; Judgment of 27 January 1928, 62 RGSt 49, 52. Known as dingliche Haftung für fremde Schuld. See Schäfer LK vor $\$ 40$ margin no. 3. The United States Supreme Court in its most recent forfeiture decision raised variations of all three of these theories to support American forfeiture law. Calero-Toledo v. Pearson Yacht Leasing Co., 416 U.S. 663, 686 (1974). See text at n. 175 infra. Cf. J.W. Goldsmith, Jr.-Grant Co. v. United States, 254 U.S. 505, 510 (1921).

65. Judgment of 9 October 1951, 1 BGHSt 351, 353. See Judgment of 10 November 1949, OLG Koblenz in 1950 NJW 78.

66. 1 BGHSt at 353-54.

67. Id. See also Judgment of 25 April 1952, 2 BGHSt 311, 312. The Federal Supreme Court in its judgment of 9 October 1951 also considered a proper legal justification to be made out if "the property owner has had a benefit, the connection of which to the [illegal] act was recognizable for him." 1 BGHSt at 353. The draft proposals of the new criminal code included such a benefit provision. Entwurf 1956 \$ 121 cl. 3; Entwurf 1960 § 113 | 2 cl. 2(b); Entwurf 1962 \& 113 If 2 cl. 2(b). The proposal was attacked as of dubious constitutionality, in part because of vagueness in defining the fault of the property owner, and was not enacted. See Eser at 232, 239-41.

68. The exclusion is usually found in GG Art. 14 \$ 1 cl. 2. Eser at 224. See text of Art. 14 quoted in $n .45$ supra. 
to avoid the constitutional requirement merely by looking to the use of the property where the property owner is neither criminally blameworthy nor even reproachable must lead to "a complete sapping of the property guarantee."69 Rather it is the fault of the owner that allows the property guarantee to be overcome. ${ }^{70}$ In this respect, the constitutional basis of the "punishment-like" forfeiture is similar to that of the punitive. ${ }^{71}$ The Federal Supreme Court has described the degree of blameworthiness required to permit a "punishmentlike" forfeiture as reproachable conduct (vorwerfbares Verhalten) ${ }^{72}$ A general showing of bad character is not sufficient. The constitution requires a finding that the owner's blameworthy conduct contributed directly to the illegal use of the property. ${ }^{73}$ It is therefore necessary that some specific act of the owner be singled out as reproachable. ${ }^{74}$

The 1968 reform of the forfeiture provisions of the German criminal code allows only a relatively narrow range of "punishment-like" forfeitures. "Punishment-like" forfeitures are possible only when the definition of a crime specifically refers to $\$ 74 a$, which establishes the conditions for such forfeitures. That section permits ordering a "punishment-like" forfeiture only if the third-party owner:

1. at least heedlessly (leichtfertig) has contributed to the thing or right having been the means or the object of the [illegal] act or its preparation, or

2. has culpably (in verwerflicher Weise) obtained the property with knowledge of the circumstances which would have permitted the forfeiture. ${ }^{75}$

By heedlessness the statute requires something greater than ordinary negligence, approaching gross negligence. ${ }^{76}$ Thus, as enacted, a "punishment-like" third-party forfeiture is permissible only if the owner has acted with near-gross negligence or has reproachably acquired the property with knowledge of a potential crime. Despite the relatively narrow scope of § 74a, Professors Baumann, Eser and

69. Eser at 224. See also Stree, supra n. 41 at 107-08. Yet, in American law "[i]t is the illegal use that is the material consideration,-it is that which works the forfeiture, the guilt or innocence of its owner being accidental." J.W. Goldsmith, Jr.-Grant Co. v. United States, 254 U.S. 505, 513 (1921).

70. Judgment of 16 June 1958, 27 BGHZ 382, 385. The avoidance of the property guarantee rests on a failure of the owner's responsibility. See Eser at 225.

71. See n. 45-47 and accompanying text supra. But it is not as satisfying as the actor's actual guilty participation in crime found in the punitive forfeiture. See Schonke-Schroder-Eser $\$ 74 \mathrm{a}$ at 815 . Jescheck says that the owner's relationship to the deed allows a "diminished guilt-reproach" (abgeschwachten Schuldvorwurf). Jescheck, Lehrbuch des Strafrechts-Allgemeiner Teil 599 (2d ed. 1972).

72. Judgment of 16 June 1958, 27 BGHZ 382, 385.

73. Judgment of 25 October 1963, 19 BGHSt 123, 126.

74. The Federal Supreme Court held the constitutional requirement not satisfled by the failure of a secured creditor to check his debtor for a criminal record. 19 BGHSt 123.

75. StGB § 74a.

76. Dreher $\S 74$ at 377 ; Eser at 225 ; Gohler, OWiG $\S 23$ at 148 ; Schönke-SchröderEser $\$ 74 a$ at 815 . 
other commentators doubt whether "punishment-like" forfeiture conforms with the guilt principle, the property guarantee and other constitutional requirements. ${ }^{77}$ Baumann sees "punishment-like" forfeiture as "a type of secondary punishment of not-punishable third parties."

\section{Other Constitutional Problems}

Critics begin, as Baumann does, with the proposition that the sanction is nothing other than a punishment. It cannot be a preventive measure; that is precluded by the requirement of blameworthiness. To the contrary, the Federal Supreme Court's own designation, "punishment-like," recognizes that the sanction is closer to punishment. Examination of the function and the goals of the "punishment-like" forfeiture, the critics contend, shows that it is nothing other than punishment. "Punishment-like" forfeiture takes property for the blameworthiness of the owner as a quasi-participant in crime. ${ }^{79}$ Eser notes that the whole tenor of the 1968 reform provisions confirm the conclusion, since they embody a mit im Spiel gewesen ("in on the crime") approach. ${ }^{80}$ Similarly, the goals of the "punishment-like" forfeiture are specific deterrence of the individual owner and general deterrence of the community at large, typical purposes of punishment. ${ }^{81}$ Also, the critics rightly find the argument unpersuasive that "punishment-like" forfeiture is not punishment because the owner is not personally prosecuted. ${ }^{82}$

If "punishment-like" forfeiture is seen as a punishment, it must meet all the constitutional and legal requirements of punishments generally. Foremost, "[a]n act can be punished only if it was an offence against the law before the act was committed."83 The critics ask, where is the statute establishing the property owner's of-

77. Baumann, Strafrecht-Allgemeiner Teil 731 (5th ed. 1968); Eser at 238-41.

78. Id. at 731 .

79. Id. at 731; Eser at 224-32 (particularly at 230); Gilsdorf, $1958 \mathrm{JZ}$ at 686-90; Gohler, OWiG at 136; Zeidler, "Strafrechtliche Einziehung und Art. 14 GG," 1954 NJW 1148,1149 [hereafter Zeidler, 1954 NJW].

80. Eser at 225.

81. Id. at 230; Jescheck, supra n. 71 at 597. Eser contends that recognition of the deterrent purpose of the "punishment-like" forfeiture is general. Eser at $230 \mathrm{n} .42$.

82. Eser calls the argument nothing more than "pure formalism," adoption of the view "that can not be, which may not be." Eser at 231. Yet, that seemed to be the view of the Federal Supreme Court in one of its first decisions in the area (creating the "punishment-like" classification). Judgment of 9 October 1951, 1 BGHSt 351, 353. Gilsdorf attacks the suggestion of the creation of a sui generis class of "punishmentlike" forfeitures as a compromise between expediency and constitutional principles. Gilsdorf, $1958 \mathrm{JZ}$ at 689 . The United States Supreme Court has adopted an argument similar to that assailed by Eser. "It is the property which is proceeded against, and ... held guilty . . . . In a criminal prosecution it is the wrongdoer in person who is proceeded against, convicted and punished. The forfeiture is not part of the punishment for the criminal offense." Various Items of Personal Property v. United States, 282 U.S. 577, 581 (1930).

83. GG Art. 103 ๆ 2, translation, supra n. 45 at 56 . 
fense ${ }^{84}$ Assuming the offense can be seen as established through reading the general forfeiture section of the new code in combination with the specific crime in which the property was used, the offense thus established must still be defined with specificity. ${ }^{85}$ Eser suggests that offenses so created by the new code may be void for vagueness. ${ }^{86}$ In another direction, $\S 74 \mathrm{a}$ creates the likelihood of punishment in the absence of criminal intent, which raises further questions, viz. the guilt principle. ${ }^{87}$ While the proportionality requirement applicable to punitive forfeitures is as fully applicable to "punishment-like" third-party forfeiture, there is no provision to assure that the (only) "quasi-guilty" owner is treated less severely than the criminally guilty principal or accessory whose act gave rise to the forfeiture. ${ }^{88}$ Absent such a provision, it is probable that an owner will be punished by the forfeiture of property worth considerably more than the fine assessed against the criminal perpetrator. More generally, the critics charge that "punishment-like" forfeiture never really clearly establishes what the conduct is that is worthy of condemnation. ${ }^{89}$ The property owner has committed no crime. Eser charges that the true motive of "punishment-like" forfeiture is to punish those suspected of complicity. Punishment for suspicion, he says, has no place in a constitutional state. ${ }^{90}$

Thus the critics argue that "punishment-like" forfeiture should be dropped as contrary to constitutional principles.91 Eser notes that in any case "punishment-like" forfeiture serves little purpose. If the owner is in fact criminally culpable he will be punishable as an accessory and the property may thus be subject to forfeiture. In other cases, the property will be subject to forfeiture as a preventive measure. ${ }^{92}$ The liberal professors who prepared the alternative draft criminal code would have solved the constitutional problems by getting rid of all except purely preventive forfeitures. ${ }^{93}$

84. Eser at 232; Gilsdorf, $1958 \mathrm{JZ}$ at 689 ; Zeidler, $1954 \mathrm{NJW}$ at 1149 . For a contrary argument, see Stree, supra n. 41 at 112-14.

85. Eser at 232; Gilsdorf, $1958 \mathrm{JZ}$ at 689,691 .

86. Eser at 233-34. One of the three proposed "punishment-like" forfeitures was dropped from the enacted code. See n. 67 supra.

87. Eser at 225-26, 234.

88. Eser at 237-38; see n. 49-61 and accompanying text supra.

89. See Eser at 236-37.

90. Eser at 234-35.

91. Eser at 238-41; Gilsdorf, $1958 \mathrm{JZ}$ at $685,689,691$. Jescheck rejects these criticisms. See Jescheck, Lehrbuch des Strafrechts-Allgemeiner Teil 644 n.17 (3d ed. 1978).

92. Eser at 239-41.

93. Baumann et al., Alternativ-Entwurf eines Strafgesetzbuches-Allgemeiner Teil $\$ 88$ at 161 (1966). A translation of the alternative draft has recently been published. Darby, Alternative Draft of a Penal Code for the Federal Republic of Germany (Am. Series of Foreign Penal Codes vol. 21, 1977). 


\section{Preventive Forfeiture}

\section{The Property Guarantee}

Forfeiture of property as a preventive measure to protect society from a specific danger has been accepted with near unanimity in German law as a legitimate instrument of the legal order and as consistent with constitutional principles. ${ }^{94}$ Perhaps for that reason it was not until the middle 1960 s that it came under scrutiny for conformity with the Basic Law. The general acceptance of some form of preventive forfeiture has continued unassailed, though with some dispute as to the exact theoretical basis of the sanction..$^{95}$ Nevertheless, discussion of preventive forfeiture has not centered on its permissibility. Instead, most commentary has been directed toward the necessary constitutional limitations imposed by the property guaranty of Art. 14.

In a decision of 16 July 1965, the Federal Supreme Court stated general principles derived from Art. 14 limiting preventive forfeiture.

Each individual case must be meticulously scrutinized for whether the encroachment to meet the danger is actually appropriate (geeignet) and whether it is required (erforderlich). Only for necessary measures is there a legal justification for the state to seize private property ... [T]he perpetrator's unlawful conduct . . . alone is not yet able to justify the forfeiture. Rather, there must also be the danger of further disruptions of the lawful order through or with the forfeited object. Finally, the measure must also be in accord with the general constitutional principle of proportionality of means. ${ }^{96}$

These three related principles-necessity (Erforderlichkeit), appropriateness (Geeignetheit) and proportionality (Verhaltnismässigkeit)-are not always kept distinct in the discussion of preventive forfeitures. ${ }^{97}$ All three are derived from the more general constitutional prohibition of excessive measures (Ubermassverbot). ${ }^{98}$ How German jurists have utilized these principles is of particular interest to the United States since American forfeitures have generally been upheld on the ground of their asserted role as preventive and regulatory measures.

It is the need of the community to protect itself from a particular danger that allows the German state to overcome the constitutional guarantee and forfeit its citizens' property. If there is in fact

94. Eser at 118-20, 249-52.

95. See Dietrichs, supra n. 27 at 47-54; Eser at 249-52. Even the liberal professors' alternative draft code allowed purely preventive forfeitures. Baumann et al., supra $\mathbf{n}$. $93, \S 88$ at $160-61$.

96. 20 BGHSt $253,255-56$ (emphasis in original; citations omitted).

97. For example, the drafters of the new code didn't keep the three ideas separate. StGB $\& 74 \mathrm{~b} \| 2$ which deals with all three is simply headed "Principle of Proportionality."

98. Eser at 195-97, 268-69; Lerche, Übermass und Verfassungsrecht 19-23 (1961). 
no need for such protection, there can be no justification for a preventive forfeiture. ${ }^{99}$ The earlier law of the Federal Republic already recognized that a preventive forfeiture could be upheld only if a real danger to the community existed. ${ }^{100}$ But under the pre-1968 law the judge was restricted in the range of actions he could take. Once he determined there was a real danger to the community he could only order a complete forfeiture or none at all; there was no middle way. To order the forfeiture would often be a greater response than necessary to protect the public, while to deny forfeiture would take insufficient account of the danger to the community. With the greater emphasis in the legal discussion of the 1960s upon the need for such a measure as a prerequisite to overcome the property guarantee, the constitutional position of such forfeitures became doubtful. Complete forfeiture could not be justifled if a lesser measure would meet the public's need for protection. ${ }^{101}$ Accordingly, first the liberal professors' alternative draft proposal, ${ }^{102}$ and eventually the 1968 reform, ${ }^{103}$ undertook a radical departure in preventive forfeiture law. The reform mandates a more accurate determination of the need for protection and enables the judge to meet the danger with a lesser sanction than complete forfeiture of the property.

The 1968 reform act takes the approach that the actual sanction ordered with respect to the property should correspond as exactly as possible to the public danger. Intrusion into the area of constitutionally protected rights will thereby be strictly limited to the minimum measure actually necessary to protect the public. This determination is to be made by the trial court. $\S .74 \mathrm{~b}$ of the new code provides:

(2) In the cases of $\S \S 74$ and $74 a$ [the general forfeiture provisions] the court shall order that the forfeiture remain reserved, and shall find a less drastic measure, if the purpose of the forfeiture can thereby be accomplished. As alternatives may be considered an order

1. to make the property unusable,

2. to remove certain fixtures or marks or otherwise alter the property, or

3. to control the property in a certain way.

If the order is complied with, the reservation of the forfeiture will be at an end; otherwise the court shall at last order forfeiture.

(3) If the forfeiture is not mandatory, it can be limited

99. Judgment of 16 July 1965, 20 BGHSt 253, 255-56 (quoted in pertinent part, text at n. 96 supra); Judgment of 16 June 1958, 27 BGHZ 382, 387-88; Eser at 249-52; Gilsdorf, $1958 \mathrm{JZ}$ at 644 ; Jescheck, supra n. 71 at 600 ; Schonke-Schroder-Eser $\$ 74$ at 812 ; Stree, supra n. 41 at 109-10.

100. Schonke-Schroder $\S 40$ at 186 (12th ed.); Zeidler, 1954 NJW at 1149.

101. Judgment of 6 November 1969, OLG Karlsruhe in 1970 NJW 394, 396; see Dietrichs, supra n. 27 at 54; Eser at 269; Stree, supra n. 41 at 110-11.

102. Baumann et al., supra n. 93 at $\$ 88$ \ 2 at 160,162 . See Eser at 269-70.

103. StGB $\S 74 b$ ๆ 2,3 (quoted in text at $n$. 104 infra). 
to a part of the property. ${ }^{104}$

Complete forfeiture of property is thus the ultimate sanction to prevent danger to the public. Before resorting to it, the trial court is to consider lesser measures and to prefer those lesser measures that would be effective.105 For example, illegally obtained drugs need only be returned to the pharmacist, not forfeited, in order to protect the public. ${ }^{106}$ The public is protected from unlicensed drivers when the car is taken into custody until such time as the driver gets a license; no forfeiture is necessary. ${ }^{107}$ In the case of the driver who cannot be allowed to drive at all, the danger to the public is averted when the driver has disposed of the car, though keeping the proceeds for himself. ${ }^{108}$

To be constitutional, a preventive forfeiture must not only be necessary to protect the community, it must also be appropriate and proportional. ${ }^{109}$ A forfeiture or lesser similar preventive sanction is appropriate only if it will in fact serve to protect the legal interest for which it is supposedly employed. ${ }^{110}$ Here it is the responsibility of the trial judge to examine the legal interest to be protected and the danger to that interest. Similarly, a forfeiture must be considered inappropriate if it is wholly inadequate to achieve the supposed goal of protection. Thus the forfeiture of an everyday item of modest value usually cannot be justified as a preventive measure. ${ }^{111}$ Finally, the preventive measure, like the punitive, must be propor-

104. StGB \& 74b If 2,3 .

105. See generally Dreher $\S 74 b$ at $379-80$; Eser at $270-74$; Gohler, OWiG $\S 24$ at 154 57; Schafer LK § 40b margin nos. 10-16; Schonke-Schróder-Eser $\S 74 \mathrm{~b}$ at 817-19.

106. Judgment of 30 July 1974, Bayerisches OLG in 1974 NJW 2060. There is some precedent for such a course in American law. See United States v. 76,552 Pounds of Frog Legs, 423 F. Supp. 329 (S.D. Tex. 1976) (allowing owner an opportunity to reprocess frog legs to bring product into conformity with federal standards).

107. See Judgment of 3 April 1974, Landgericht [LG] Karlsruhe in 1974 NJW 1257.

108. See Judgment of 5 November 1973, OLG Braunschweig in 1974 Monatsschrift fur Deutsches Recht [MDR] 594. The mere promise of the owner not to use the property illegally is probably not sufficient. Schonke-Schroder-Eser $\$ 74 \mathrm{~b}$ at 819 ; contra Judgment of 6 November 1969, OLG Karlsruhe in 1970 NJW 394, 396.

109. Judgment of 16 July 1965, 20 BGHSt 253, 255-56 (quoted in pertinent part, text at $\mathbf{n} .96$ supra). The appropriateness requirement is sometimes spoken of as the "goal suitability" (Zwecktauglichkeit) criterion. Eser at 274.

110. Eser at 274-77; Schonke-Schroder $\$ 40$ at 486 (12th ed.). Thus the forfeiture of uncustomed goods is appropriate as a preventive measure to assure the government its revenues and to protect the public from black market goods only so long as the owner is unavailable or unwilling to pay the duty and otherwise comply with regulations. If the owner is willing to pay the duty and comply with regulations, a forfeiture of the goods is inappropriate as a preventive measure and can only be justified as punishment. Eser at 275. Forfeitures that would be inappropriate in Germany are permissible in the U.S. See United States v. Four Pinball Machines, 429 F. Supp. 1002 (D. Ha. 1977) (ordering forfeiture of gaming machines despite owner's willingness to pay the use tax owing from the lessee of the devices); Dickey, "Survivals from More Primitive Times: Customs Forfeitures in the Modern Commercial Setting," 7 Law \& Policy in Int. Bus. 691 (1975).

111. Judgment of 16 July 1965, 20 BGHSt 253, 256 (holding a typewriter could not be forfeit as a preventive measure). Cf. Eser at 276-77. 
tionate. ${ }^{112}$ If the danger to the community, though real, is slight, and the commercial value of the property great, the judge must deny the forfeiture. ${ }^{113}$ In the reform act of 1968 , to the extent that appropriateness and proportionality are dealt with by statute, they fall under the provisions of $\S 74 \mathrm{~b}$.

\section{What Gives Rise to a Preventive Forfeiture?}

Property dangerous to the community and subject to preventive forfeiture is of two types, distinguished by whether the danger exists in the abstrakt or is only relativ. ${ }^{114}$ Certain property is by its nature and construction dangerous to the community. Military explosives, toxins and poisoned foods are dangerous in the abstract. In contrast, property which is ordinarily safe can become dangerous in certain circumstances. A hunting rifle is safe if owned by a responsible citizen, but is relatively dangerous in the hands of a madman. In the past, the abstract category of property dangerous regardless of circumstances has been the core of preventive forfeiture law; some commentators have suggested, without general acceptance, that preventive forfeitures should be limited to that category. ${ }^{115}$ Professor Eser would not so limit preventive forfeiture, but would abolish the distinction between abstract and relative dangers. He correctly observes that very few objects can be said to be absolutely dangerous. ${ }^{116}$ Instead of maintaining a strict distinction between abstract and relative, Eser would have courts look at all the circumstances, including the nature and construction of the property, the objective facts of the situation, and the personality of the criminal actor, if the actor is the owner of the property. The appropriate sanction to meet the danger so determined would then be ordered.117

The 1968 reform act follows past interpretations of what constitutes a danger giving rise to a preventive forfeiture. $\$ 74$ provides that property may be forfeit if "by its nature and under the circumstances it endangers the general public or the danger exists that it will serve in the commission of further illegal acts."118 The primary clause, that of property dangerous "by its nature and under the circumstances" encompasses both the abstract and the relative catego-

112. Judgment of 16 July 1965, 20 BGHSt 253, 256.

113. Gohler, OWiG § 22 at 145 ; Schonke-Schröder $\S 40$ at 486 (12th ed.).

114. Judgment of 15 December 1970, OLG Oldenburg in 1971 NJW 769, 770; Creifelds, "Die strafrechtliche Einziehung gegen den 'Dritteigentumer'," 1955 Juristische Rundschau [JR] 403, 404-07 [hereafter Creifelds, $1955 \mathrm{JR}$ ]; Eser at 258-60; Gohler, OWiG § 22 at 145; Schonke-Schroder-Eser $\$ 74$ at 812 . Cf. Dreher $\$ 74$ at 374.

115. See e.g., Stree, supra n. 41 at 11-12. See also, Eser at 259-61. Cf. U.S. v. One 1972 Datsun, 378 F. Supp. 1200 (D.N.H. 1974).

116. Eser at 259-60. For example, some explosives, though dangerous in public trade, have their place in the hands of a responsible contractor. Forged postage stamps present no danger in the reference collection of an honest philatelist or state philatelic library.

117. Eser at 262-64.

118. StGB $\$ 74$ ๆ 2 cl. 2. 
ries. ${ }^{119}$ The possibility envisioned in the secondary clause was recognized well before the 1968 reform act and requires further elaboration. ${ }^{120}$ Forfeiting property where danger exists of further illegal use potentially gives preventive forfeiture a very broad sweep. However, the statute is not to be so widely read.121 Emphasis must be placed on the danger of actual further illegal use. Before property ordinarily of legal use may be forfeit on account of a risk of further illegal use, the trial judge must find "tangible criteria" (konkrete Anhaltspunkte) which in their "outline" show the danger to be "already fairly clearly definable." 122 A mere suspicion of some uncertain future criminal activity with the property is not sufficient.123 Eser has provided a good general statement of the widest permissible extent of preventive forfeiture:

Grounds for a preventive forfeiture of property involved in the crime are made out, if on the basis of specified established facts and upon assessment of all the circumstances of the individual case, ... the strong probability exists that the property is injuring legally protected interests or will serve in the commission of unlawful acts. ${ }^{124}$

\section{Compensation}

Besides limiting the circumstances in which forfeiture may be ordered, the 1968 reform act took further steps to establish a secure constitutional foundation when forfeiture is actually ordered. The reform safeguards third parties either by continuing their rights in the property after forfeiture or by giving them compensation. $\S 74 \mathrm{e}$ of the 1975 Code includes the general rule that third-party rights shall continue notwithstanding the forfeiture, ${ }^{125}$ with two important exceptions. If the forfeiture is a preventive measure to protect the public, the court must order the extinction of all rights in the property $^{126}$ though innocent third parties will still have a claim to compensation. ${ }^{127}$ Moreover, the court may order the extinction of the rights of a third party who is sufficiently blameworthy to meet the requirements of a "punishment-like" forfeiture. ${ }^{128}$ In the event the court orders a forfeiture, unaware of the rights of third parties or without a sufficient legal foundation to extinguish third-party rights,

119. Gohler, OWiG $\S 22$ at 145 ; Schonke-Schroder-Eser $\$ 74$ at 812 .

120. See Creifelds, $1955 \mathrm{JR}$ at 404-07.

121. Although if the section were so widely read, it would still be subject to the constitutional prohibition of excessive means and the statutory formulation of that prohibition in StGB $\S 74 \mathrm{~b}$. See Judgment of 15 December 1970 , OLG Oldenburg in 1971 NJW 769.

122. Schønke-Schroder-Eser $\S 74$ at 812-13.

123. Id. Schafer LK $\S 40$ margin no. 49.

124. Eser at 268 .

125. StGB \& 74e I 2. Cf. OWiG \& 26 I 2. Under the 1871 Criminal Code, third party rights were extinguished. Schonke-Schroder $\S 40$ at 191 (12th ed.).

126. StGB § 74e \| 2. Cf. OWiG \& 26 ๆ 2.

127. StGB $\$ 74 f . C f . O W i G ~ \& 24$.

128. StGB $\S 74$ e 2 . Cf. OWiG $\S 26$ ๆ 2. 
$\S 439$ of the Code of Criminal Procedure, enacted as a part of the 1968 reform, gives the third party an action to recover his property or vindicate his rights. ${ }^{129}$

$\S 74 \mathrm{f}$ of the Criminal Code of 1975 directs that innocent third parties be reimbursed by the state when their property or rights are taken or otherwise diminished in value in consequence of forfeiture proceedings. ${ }^{130}$ Compensation is to be at the full commercial value of the taking or diminution. ${ }^{131}$ Principals and accessories to the crime have no claim to compensation. ${ }^{132}$ Their misuse of property ends the constitutional right to compensation even with preventive forfeitures. ${ }^{133}$ Nor is the owner who has so misbehaved as to merit a "punishment-like" forfeiture entitled to reimbursement. ${ }^{134}$

The compensation requirement is essential to a fair and effective system of preventive forfeiture. Without it the statutory scheme would probably have to choose between protecting the innocent property owner or the general public. For example, permitting forfeiture only if the owner is culpable would protect innocent owners but would leave the public exposed to dangerous property still in private possession. Allowing forfeiture whenever there is a substantial danger would protect the public, but at the expense of the innocent owner. The German solution of allowing forfeiture when there is a substantial danger to the public but requiring compensa-

129. StPO $\S 439$. Under $\S 439$ the third party owner must seek the return of the property or the vindication of his right within one month of learning of the forfeiture and in no event later than two years after the effective date of the forfeiture order. Should the third party owner delay past those time limits, he can no longer reclaim the property or right, but may still secure compensation for the taking suffered. See Kleinknecht, StPO § 439 at 904-06; Schonke-Schroder-Eser $\$ 74$ at 826 . Cf. OWiG $\S 87$ ๆ4.

130. StGB § $74 f$ ๆ 1 . Cf. OWiG § 24 ๆ I.

131. Dreher § 74f at 391 ; Gohler, OWiG § 28 at $174-75$; Schønke-Schröder-Eser $\S 74 f$ at 829 .

132. StGB § $74 f$ ๆ 1 . Cf. OWiG § 28 ๆ1.

133. Gobler, OWiG $\S 28$ at 171 . The preventive forfeiture can thus take on certain attributes of punishment, since in some cases the guilty owner will suffer the additional "penalty" of not receiving compensation where the innocent third party will. German commentators have not discussed this issue. But see Judgment of 5 November 1973, OLG Braunschweig in $1974 \mathrm{MDR} 594$ (recognizing the issue). This discrepancy will not be apparent in the case of abstractly dangerous property, since such property will be deemed without commercial value and neither the principal nor the third party will be compensated. Where the discrepancy will be evident is in the case of relatively dangerous property, particularly where the property is taken on account of the danger of further illegal use. But here the guilty principal will be protected to a certain extent by the requirements of necessity and proportionality. Moreover, Professor Eser suggests the trial judge should take this forfeiture into account in deciding the main sentence. Telephone interview with Professor Albin Eser (19 June 1977). See Dreher $\S 74 \mathrm{~b}$ at 379 . See also $n$. 61 and accompanying text supra.

134. StGB $\S 74 f$ ๆ 3 . Cf. OWiG $\S 28$ ๆ 2. Reimbursement is also not required if the property is subject to an uncompensated taking under some other provision of law. $\S 74 \mathrm{f}$ does give the guilty owner a protection not required by the Basic Law: if the forfeiture will work an unjust hardship, the owner may be compensated. StGB $\$ 74 f$ ๆ 3. Cf. OWiG \& 28 ॥ 3. See Eser at 374-77. 
tion to the innocent owner effectively balances the public and private interests.

\section{E. Special Forms of Ownership}

German law has ordinarily required that forfeiture as punishment is permissible only when the principal or an accessory owns the property at the time of the order. ${ }^{135}$ This requirement was raised to constitutional rank by the Federal Supreme Court interpreting the guilt principle in the early 1950s. One consequence is that a punitive forfeiture is not permissible if the property is jointly owned and only some of the owners are guilty of the crime. ${ }^{136}$ In that case a forfeiture is permissible only on other grounds, either as a "punishment-like" or preventive forfeiture.

The Federal Supreme Court extended the requirement of complicity of all owners to include all forms of ownership, even those that are purely formal. Thus even in the case of contingent forms of ownership, such as rights held as a secured creditor or as a conditional seller, it is necessary to establish either complicity, sufficient guilt for a "punishment-like" forfeiture or preventive grounds. ${ }^{137}$ The Court soon recognized the undesirability of allowing the criminal to escape a punitive forfeiture merely because he had failed to make the final installment payment. Therefore the Federal Supreme Court held that a forfeiture might be declared if the state agreed beforehand to assume all the obligations of the owner-criminal to the security holder or conditional seller. ${ }^{138}$

A number of commentators have argued that the 1968 reform act has changed the situation with respect to the special forms of ownership just discussed. Especially Eser has argued that the new broad-reaching compensation provisions allow the courts to look only to commercial ownership of the property and to limit purely formal owners to their claim for compensation. ${ }^{139}$ The Federal Supreme Court however has explicitly rejected Eser's position and adhered to its position under the old code. ${ }^{140}$ But the Court has reached a basically similar result by an imaginative reading of the

135. StGB $\$ 40$ (1953). Schafer LK $\S 40$ margin no. 28 (Gehoren bedeutet: Alleineigentumer sein.) (emphasis in original). Schonke-Schroder $\$ 40$ at 188-89 (12th ed.). One consequence of the requirement that the property belong to the perpetrator was that property of a juristic person could not be forfeit, even though the principal was acting as a representative of the corporate entity. Schwarz-Dreher $\S 40$ at 124 . This result was overcome by a special provision of the new code. StGB $\$ 75$.

136. Judgment of 18 October 1951, 2 BGHSt 337; Judgment of 25 April 1952, 2 BGHSt 311.

137. Judgment of 25 April 1952, 2 BGHSt 311.

138. Judgment of 21 June 1955, 8 BGHSt 70.

139. Eser, "Zum Eigentumsbegriff im Einziehungsrecht," 1972 JZ 146-49. See also Esser, "Anmerkung" [to BGH Judgment of 24 August 1972], 1973 JZ 171-73; Meyer, "Anmerkung" [to BGH Judgment of 24 August 1972], 1973 JR 338; Schonke-SchroderEser $\$ 74$ at 811 ; Schonke-Schroder $\$ 40$ at 189 (12th ed.).

140. Judgment of 24 August 1972, 25 BGHSt 10; Judgment of 28 September 1971, 24 BGHSt 222. 
reform act. Before 1968 only objects could be forfeit, not rights. ${ }^{141}$ Now, under the 1968 act, rights too may be forfeit if illegally used or obtained. ${ }^{142}$ The Federal Supreme Court interpreted this provision to allow the state to forfeit whatever right the security giver or conditional buyer has in the property. The Court adopted the theory that the owner's misuse of the object effected a misuse of his rights in the object as well. ${ }^{143}$ Eser has criticized this approach as unnecessarily complicated and as possibly leading to future problems. ${ }^{144}$

\section{F. Profits of Crime}

In addition to the forfeiture of property created by or used in crime, German law employs the related sanction of deprivation of profits of crime. Depriving the wrongdoer of the profits of his illegal activity is not thought to be punishment in the usual case. ${ }^{145}$ Nor is it considered a preventive measure. Instead it is seen as a measure separate and distinct from the punitive and preventive forfeitures discussed above. The 1975 criminal code treats deprivation of the profits of crime separately from the forfeiture of the instruments and products of crime. The two sanctions are dealt with in different code sections and under different names. ${ }^{146}$ In discussing the former sanction, commentators have pointed out the reparative effect of taking away the profits of crime. The deprivation effects a restoration of the legal order by denying the illegitimate receiver the unlawfully obtained enrichment. ${ }^{147}$ Ordinarily, only the criminal will be subject to deprivation. In appropriate circumstances however, third parties may lose property as profits of crime. Third parties can be subject to deprivation only if the criminal acted illegally on behalf of the third party or if the third party culpably accepted the profit with knowledge of the circumstances. ${ }^{148}$

\section{The Procedure for Imposing Forfeiture}

For nearly a century American law regarded the separate in rem action as the only proper procedural form in which to declare a forfeiture of property. Forfeiture in a criminal prosecution was consid-

141. Schonke-Schroder $\$ 40$ at 188 (12th ed.); Schwarz-Dreher $\S 40$ at 123-24.

142. Gohler, OWiG § 22 at 140; Schonke-Schroder-Eser $\S 74$ at 807.

143. Judgment of 24 August 1972, 25 BGHSt 10; accord Judgment of 19 October 1973, OLG Karlsruhe in 1974 MDR 154. 32.

144. Eser, "Anmerkung," 1973 JZ 171-73. See also Schafer LK § 40 margin nos. 29-

145. Dreher $\S 73$ at 361-62; Lackner $\S 73$ at 335; Schonke-Schroder-Eser at 792.

146. Deprivation (Verfall) is dealt with in StGB $\$ \S 73-73 d$; forfeiture (Einziehung), both punitive and preventive, is dealt with in StGB $\$ \S 74-75$. StGB $\$ \S 76-76$ a are common to both sanctions.

147. Dreher $\S 73$ at 361 ; Lackner $\S 73$ at 334 . Lackner considers deprivation a measure "for reparation of violated law" (zur Wiederherstellung des verletzten Rechts). Id. at 335. Eser calls it a "quasi conditional equalization (or compensation) (Ausgleich) measure." Schonke-Schroder-Eser $§ 73$ at 792.

148. StGB \& 73 IT (3) \& (4). See Dreher $\S 73$ at 365-66; Schönke-Schroder-Eser $\S 73$ at $798-800$. 
ered inappropriate. ${ }^{149}$ In contrast, German law has considered forfeiture proceedings independent of the prosecution of the perpetrator to be the exceptional method of procedure. $\$ 40$ of the Criminal Code of 1871 specifically provided that "[t]he forfeiture order must be pronounced in the sentence."150 Nevertheless, $\S 42$ recognized exceptional circumstances in which an independent suit for forfeiture might be brought. "If . . . no specific person can be prosecuted or convicted, the measures [prescribed in $\S 40$ ] may be imposed independently." 151 When a specific person can be prosecuted, both under the old law and the new, the forfeiture was and is to be imposed in that prosecution.

\section{A. Criminal Prosecution}

If the owner of the property is not subject to prosecution, the forfeiture is to be imposed in prosecution of the principal or accessory whose acts gave rise to the circumstances allowing a forfeiture. ${ }^{152}$ Under the law in effect until 1968, the third-party owner had no right to intervene in the prosecution of the criminal defendant to protect his property. This practice was challenged in the course of reconsidering forfeiture law in light of the Basic Law. Both the Federal Supreme Court and a number of commentators expressed doubt that such third-party forfeitures conformed with the constitutional requirement that "[i]n the courts everyone shall be entitled to a hearing in accordance with law."153 Consequently in amending the substantive law of forfeiture, the drafters of the 1968 reform amended the Code of Criminal Procedure to give a third-party owner his constitutional right to be heard. ${ }^{154}$ Under the fairly elaborate provisions enacted, the property owner is given the right of a criminal defendant with certain exceptions. ${ }^{155}$ In case the owner does not intervene in the perpetrator's trial and the trial court has reason to believe such an owner exists, the court is required to investigate. ${ }^{156}$ Finally, if the third party still does not have the opportunity to be heard, he is given an opportunity to bring a suit to recover his property. ${ }^{157}$

\section{B. Independent Proceeding}

Though the 1968 reform act made a number of changes in the

149. See n. 3-5 and accompanying text supra.

150. StGB \& 40 ๆ 2 (1953).

151. StGB \& 42 (1953).

152. Schonke-Schroder-Eser $\S 74$ at 814 ; Schonke-Schroder $\S 40$ at 191 (12th ed.); Schwarz-Dreher $\$ 40$ at 126-27.

153. GG Art. 103 ๆ 1 , translation, supra $n$. 45 at 56. Judgment of 29 October 1963,19 BGHSt 123; Dietrichs, supra n. 27 at 91-95; Schonke-Schroder $\S 40$ at 192 (12th ed.).

154. StPO $\$ \S 431-39$. See Kleinknecht, StPO at $18,887$.

155. Bode, "Das neue Recht der Einziehung im Strafrecht nach dem EGOWiG," 1969 NJW 1052, 1055; Kleinknecht, StPO § 433 at 896.

156. StPO \& 432 ข II.

157. StPO § 439 . See n. 129 supra. 
procedure for imposing forfeiture as part of the criminal prosecution, it did not greatly change the law of the somewhat exceptional independent forfeiture proceeding. For the most part the new provisions codify judicial and scholarly interpretation of $\S 42$ of the Criminal Code of 1871. All three varieties of forfeiture-punitive, "punishment-like," and preventive-may on some occasions be imposed in separate proceedings. ${ }^{158}$ Use of the independent proceeding does not change the nature of the forfeiture so imposed.159 In fact, the nature of the forfeiture significantly affects the availability of the independent proceeding; non-preventive forfeitures may be imposed in independent proceedings in a much narrower range of circumstances than preventive ones.

A non-preventive forfeiture may be imposed in an independent proceeding only when "on factual grounds no specific person can be prosecuted or convicted." 160 Only such factual obstacles as make prosecution impossible without affecting the material punishability of the crime qualify. ${ }^{161}$ Thus an independent forfeiture proceeding may be maintained if the perpetrator has fled the jurisdiction or cannot be discovered, ${ }^{162}$ but not when the perpetrator-owner has died, for then there could no longer be a prosecution. ${ }^{163}$ Nor can an independent proceeding for a punitive forfeiture be maintained when the prosecution has been abandoned or has failed.164 In general, the legal impossibility of prosecution does not allow an independent proceeding for a punitive forfeiture. ${ }^{165}$ If however the state attorney decides to forego the criminal prosecution, then by explicit statutory provision, an independent proceeding may be brought. ${ }^{166}$ Assuming the prerequisites for an independent punitive forfeiture proceeding are met, the state must also prove every other material element of the crime. Thus the state cannot obtain a forfei-

158. See generally Gohler, OWiG $\S 27$ at 167-70; Schonke-Schroder-Eser $\S 76 a$ at 834-36.

159. Schonke-Schroder $\S 42$ at 194 (12th ed.). The use of the independent proceeding does reduce the vote required for the verdict to a simple majority (from either an absolute majority or two-thirds). Kleinknecht, StPO $\S 440$ at 908 .

160. StGB \& 76a ๆ 1 .

161. Göhler, OWiG § 27 at 168 ; Schonke-Schroder-Eser $§ 76 a$ at 769.

162. Id.

163. Id. The Reich Supreme Court allowed the forfeiture in spite of the actor's death. Schönke-Schroder-Eser $\S 76 a$ at 834 . See Kahn, AO § 414 at 509 .

164. Judgment of 31 March 1954, 6 BGHSt 62. Formerly, a preventive forfeiture was also barred by abandonment or failure of the prosecution. Kuhn, AO $\$ 414$ at 509; Schonke-Schroder-Eser $\$ 76 a$ at 835 . StGB $\$ 78$ in now makes such a preventive forfeiture possible. Judgment of 14 February 1975, OLG Stuttgart in 1975 MDR 681. A similar distinction has been made in American law: a failure in prosecution bars a subsequent punitive forfeiture, but not a remedial one. Coffey v. United States, 116 U.S. 436 (1886); Stone v. United States, 167 U.S. 178 (1897). See also One Lot Emerald Cut Stones \& One Ring v. United States, 409 U.S. 232 (1972); Note supra n. 1 at 789-90. 165. Gohler, OWiG $\S 27$ at 168-69; see Judgment of 31 March 1954, 6 BGHSt 62.

166. StGB \& 76a ๆ 3. In American law it was once held unconstitutional to impose a punitive forfeiture in a separate proceeding. Greene v. Briggs, $10 \mathrm{~F}$. Cas. 1135 (C.C.D.R.I. 1852) (no. 5,764); Fisher v. McGirr, 67 Mass. (1 Gray) 1, 36-44 (1851); Hibberd v. People, 4 Mich. 125 (1856). See Note, supra n. 1 at 784-87. 
ture for an attempt not punishable in the criminal law. ${ }^{167}$ Where the state brings an independent forfeiture proceeding because it has been unable to discover the perpetrator of the crime, it must still prove that some unknown person did fulfill all the elements of the crime. ${ }^{168}$

A preventive forfeiture may be sought in an independent proceeding whenever a personal prosecution is impossible, whether on factual or legal grounds. ${ }^{169}$ Thus a preventive forfeiture is not precluded by a statute of limitations or by an amnesty. ${ }^{170}$ It is necessary to prove all the elements required for a preventive forfeiture in a personal prosecution. ${ }^{171}$

\section{Some Remarks on American LaW}

As noted at the outset of this comment, American courts have avoided a constitutional analysis of forfeiture law comparable to that undertaken in Germany, by reliance on a legal fiction of guilty property and supposed historical traditions of our law. Forfeiture has been treated by American courts as a unique form of sanction, completely apart from the general scheme of sanctions. Since forfeiture affects title to property, courts have held it to be necessarily in rem. If in rem, we are told it is necessarily civil in form and not punitive in effect. When the constitutionality of forfeiture has been challenged, our courts have invariably fallen back on the three positions of history, legal fiction and the supposed in rem nature of forfeiture. ${ }^{172}$ Yet, were these the only bases for constitutionality, our courts would long ago have abolished forfeiture altogether. While history may create a presumption of constitutionality, past practice alone will never validate law. ${ }^{173}$ Legal fiction and procedural characterization cannot even raise a presumption. But, as we have seen in examining the German law, there are a number of valid reasons to support forfeiture. Indeed, American courts in upholding our law have recognized the very same rationales relied upon in Germany. Unfortunately our courts have only incidentally referred to these rationales and have focused instead upon the illusory rationales of history, legal fiction, and procedural form. There is no better example than the 1974 decision of the U.S. Supreme Court upholding a Puerto Rican forfeiture statute, Calero-Toledo v. Pearson Yacht

167. Eser at 53; Schönke-Schröder-Eser § 76a at 834.

168. Gohler, OWiG $\S 27$ at 168 . Gilsdorf argues against allowing punitive forfeitures where the actor is unknown as contrary to a personal-guilt-oriented law of punishment. Gilsdorf, $1958 \mathrm{JZ}$ at 688 .

169. StGB \& $76 a$ ๆ 2.

170. Góhler, OWiG $\S 27$ at 168 ; Schonke-Schroder-Eser $\S 76 a$ at 835 .

171. Schonke-Schroder-Eser $\$ 76 a$ at 835 .

172. See e.g., Calero-Toledo v. Pearson Yacht Leasing Co., 416 U.S. 663 (1974) [noted in 60 Cornell L. Rev. 467 (1975)].

173. See Justice Holmes' remarks in Jackman v. Rosenbaum Co., 260 U.S. 22, 31 (1922) and Justice Story's comments in 1 Am. Jurist 1, 2 (1829). 
Leasing Co. ${ }^{174}$ After a six-page discourse on the history of forfeiture, the Court in a single paragraph of three sentences explains what must be the true basis of American forfeiture law:

Plainly [such] forfeiture statutes further the punitive and deterrent purposes that have been found sufficient to uphold, against constitutional challenge, the application of other forfeiture statutes to the property of innocents. Forfeitures of conveyances that have been used-and may be used again-in violation of the narcotics laws fosters the purposes served by the underlying criminal statutes, both by preventing further illicit use of the conveyance and by imposing an economic penalty, thereby rendering illegal behavior unprofitable. To the extent that such forfeiture provisions are applied to lessors, bailors, or secured creditors who are innocent of any wrong doing, confiscation may have the desirable effect of inducing them to exercise greater care in transferring possession of their property. ${ }^{175}$

As we have seen in German law, almost any one of these arguments might support a particular forfeiture in a specific situation. The flaw in the Supreme Court's analysis is that the Court raises these arguments briefly to support all forfeitures without ever showing how any single argument supports the forfeiture in Calero-Toledo. The Court does not even attempt to place this particular forfeiture within the general scheme of sanctions, as a punishment or as some other measure, and then apply the appropriate constitutional requirements to the facts of the case.

One reason for the Supreme Court's reluctance to place forfeiture into the general scheme of sanctions may be the presently unsettled divisions between the various forms of sanctions. It has become increasingly apparent that the traditional division between criminal and civil is inadequate. The civil and criminal labels tell only the form of process employed without ever describing the character of the sanction inflicted. That a suit is labeled civil does not imply that it does not impose punishment. Punishment has long been inflicted by civil process, as in tort suits assigning punitive damages, private qui tam suits, and government civil penalty actions. Yet, as Professor Clark has pointed out, the recognition of punishment in civil suits has been imperfect and the line between civil and criminal punishment unclear. ${ }^{176}$ More imperfect still has been the division between what the U.S. Supreme Court has called punitive and remedial. Traditionally in American law, "remedial" corresponded to compensation for a wrong done or repair for an injury suffered. More recently however, the Supreme Court has used remedial in a broader sense when the government is plaintiff. Sanc-

174. 416 U.S. 663 (1974).

175. Id. at $686-88$ (citations omitted).

176. Clark, "Civil and Criminal Penalties and Forfeitures: A Framework for Constitutional Analysis," 60 Minn. L. Rev. 379, 382-84, 388-89 (1976). 
tions which do not strictly repair an injury may nevertheless be described as remedial in this broader sense if they protect or promote an appropriate governmental function or interest. ${ }^{177}$ Since a multiplicity of purposes falls within the Court's use of the term "remedial," Professor Clark's choice, "nonpunishment," might appear preferable as a neutral description. In this category, whether called remedial or nonpunishment, Professor Clark has distinguished several different purposes including compensation, regulation (frequently also called prevention), taxation, and treatment. ${ }^{178}$ For present purposes, both procedural forms of punishment, civil and criminal, may be treated together, since the choice of process should not affect the standing of a forfeiture as against the substantive constitutional guarantees of property and freedom from excessive punishment. On the other hand, it will be necessary to distinguish between the various different forms of nonpunishment, since the effect of the substantive guarantees will be different depending upon the rationale of the sanction involved. For example, a forfeiture might be upheld independently as either compensation or as regulation (prevention), but must fall if it fails to satisfy the requirements of at least one form of sanction. To test the forfeiture in Calero-Toledo then requires reference to the facts of the case, the law involved and comparison to the relevant constitutional guarantees.

The facts in Calero-Toledo were stipulated at trial in the threejudge district court. The owner, Pearson Yacht Leasing Company, was a lessor of pleasure yachts. One of its yachts under long-term lease was seized when the lessee was discovered possessing a small quantity of marijuana while on board. The lease agreement specifically prohibited the use of the yacht for unlawful purposes. The owner Pearson "did not know that its property was being used illegally for an illegal purpose and was completely innocent of the lessee's criminal act." 179 The yacht was subject to forfeiture under a Puerto Rican narcotics statute providing for forfeiture of "all conveyances . . . which are used or are intended for use, to transport, or in any manner to facilitate ... possession [of a controlled substance]."180 On these facts, can any one of the Supreme Court's arguments above support this particular forfeiture?

If the forfeiture is to be upheld as a punitive measure, it must be a punishment of a particular person for a specific act or failure to act. ${ }^{181}$ The forfeiture of the yacht could be a legitimate punishment

177. See e.g., United States ex rel. Marcus v. Hess, 317 U.S. 537 (1943).

178. Clark, supra n. 176 at $463-91$.

179. Pearson Yacht Leasing Co. v. Massa, 363 F.Supp. 1337, 1340 (D.P.R. 1973), rev'd sub nom, Calero-Toledo v. Pearson Yacht Leasing Co., 416 U.S. 663 (1974).

180. Id.

181. Even if one allows punishment in the absence of blameworthiness, one must still require a specific act or failure to act to invoke the punishment. If there is nothing that the person subjected to punishment did or should have done that causes the punishment, then the punishment is wholly random. See Arendt, Origins of Totalitarianism 433, 466-68 (2d ed. 1968) (discussing the important role of random punishment in a totalitarian state). 
of the criminal who possessed the marijuana. ${ }^{182}$ That punishment of the criminal would not however explain why Pearson is penalized and not compensated. Pearson may not have been guilty of a crime, but it must have done something or failed to do something to warrant a punitive sanction. ${ }^{183}$ The Court said it was prepared to uphold the forfeiture of the interests of wholly innocent lessors in order to induce them "to exercise greater care in transferring possession of their property." In denying Pearson compensation, the Supreme Court noted that there had been "no allegation . . . that the company did all that it reasonably could to avoid having its property put to an unlawful use."184 In other words, the Court appears to say that the forfeiture statute involved imposes an affirmative duty on citizens to guarantee that their property is not used illegally. ${ }^{185}$ Failure in that duty then supports penalizing the citizen by taking his property. But the Court does not give any indication of the source of its determination that the legislature has imposed such a duty. Assuming that evidence of such a legislative intent could be found, it is doubtful that the imposition of a duty of this nature could withstand constitutional scrutiny. Perhaps the legislature might permissibly make an owner responsible for whatever use is made of particularly dangerous property, but not of ordinarily harmless property. The facts of Calero-Toledo show the absurdity of such an absolute duty. The government itself cannot keep marijuana out of its jails and army bases, where it has far more efficient means of supervision than the lessor has over his customers. The only way Pearson Yacht Leasing could assure that its property is never used for illegal purposes would be to stop leasing yachts.

If the forfeiture in Calero-Toledo cannot be upheld as a punishment, perhaps it can be endorsed as some form of "nonpunishment" (or remedial measure). The Supreme Court raises a preventive rationale when it suggests that the forfeiture serves to insure that the yacht is not put to further illegal use. But the Court does not explain why such a drastic means as forfeiture was permissible when a far less burdensome means not affecting the property rights of an innocent owner was available to protect the community. The public's need for protection would have been equally satisfied by taking the yacht from the lessee and returning it to Pearson Yacht Leasing. There was no suggestion that the particular yacht involved was more likely to be used unlawfully than any other yacht. The yacht was not specially outfitted to serve criminal purposes. There was no reason to deny the innocent yacht leasing company the return of the vessel. The mere possibility that the property might be used in the future for illegal purposes cannot be sufficient without more; ${ }^{186}$ that

182. Here it is possible that such a punishment would be excessive.

183. The failing required of Pearson may not have to be culpable, but there must be some act or failure to act that can be pointed to. See n. 181 supra.

184. 416 U.S. at 690.

185. Cf. n. 63 and accompanying text supra.

186. The necessary "something more" is not supplied by the past illegal use by the 
possibility exists with any property and would justify the forfeiture of any vessel or vehicle. Here there were no tangible criteria showing a probability of further illegal use. A German court looking at a similar situation would almost surely disallow the forfeiture for failure to show the requisite necessity. ${ }^{187}$ It might also question the forfeiture on proportionality grounds, since the commercial value of the yacht is great and the danger to the community of de minimis use of marijuana slight. ${ }^{188}$ Furthermore, a German court might doubt the appropriateness of forfeiture when the vessel is merely the locale of possession and not the means. ${ }^{189}$ In any case, even if the forfeiture could somehow be upheld as a preventive measure, a German court would require compensation to the innocent leasing company to the full commercial value of the interest taken. ${ }^{190}$ American courts should recognize, as their German counterparts already have, that the burden of a preventive forfeiture should not fall on the innocent owner, but upon the community-at-large which, after all, the preventive forfeiture is designed to serve.

Although it appears that the forfeiture in Calero-Toledo cannot be sustained on either of the two major grounds of punishment or prevention, the taking of the yacht might still be upheld on other grounds. The Supreme Court suggests that the forfeiture serves as an "economic penalty, thereby rendering illegal behavior unprofitable."191 By this the Court may mean that the forfeiture is analogous to a monetary penalty. If so, the objections to applying a punitive measure to the facts of Calero-Toledo, already discussed above, apply and the forfeiture cannot be sustained. On the other hand, the Court may be alluding to a rationale similar to that of the German sanction of deprivation of the profits of crime. ${ }^{192}$ Yet it is hard to find profit in the mere possession of marijuana. On the facts of Calero-Toledo, it seems impossible. The only conceivable profit Pearson Yacht Leasing Company received from the crime was the portion of the rental above the company's costs paid by the lessee. In the ordinary commercial case, that percentage would be only a small fraction of the company's overall interest in the vessel. To reach that small interest can hardly justify taking the whole yacht.

lessee. In the hands of Pearson, there is no more likelihood of this yacht being used illegally than any other of Pearson's yachts.

187. See n. 99-108 and accompanying text supra. Professor Clark has independently reached an analysis of American "preventive" forfeiture law that is very similar to the German. See Clark, supra n. 176 at $479-81$.

188. See n. 112-13 and accommpanying text supra.

189. See n. 109-11 and accompanying text supra. Three American courts have made essentially this distinction. See Griffis v. State, 356 So.2d 297 (Fla. 1978). State v. One 1972 Grand Prix 2-Door Hardtop, 242 N.W.2d 660 (S. Dak. 1976); State v. One Porsche 2-Door, 526 P.2d 917 (Utah 1974). These three cases require "transportation to accomplish possession" instead of mere "transportation with possession"; this rule has been explicitly rejected in the federal system. See United States v. One Clipper Bow Ketch Nisku, 548 F.2d 8 (1st Cir. 1977).

190. See n. 125-34 and accompanying text supra.

191. 416 U.S. at 687.

192. See n. 145-48 and accompanying text supra. 
In any case, Pearson's "profit from crime" is so attenuated from the criminal act that, coupled with Pearson's own total lack of complicity, it is inconceivable that any portion of the rental can qualify as a profit of crime subject to deprivation.

Finally, in a footnote, the Supreme Court suggests yet another potential rationale on which to uphold the forfeiture. The forfeiture, we are told, can serve as a valid means of compensating the government for the costs of enforcing the criminal law. ${ }^{193}$ Professor Clark has discussed the constitutional infirmities of requiring the criminal defendant to make such "compensation." Clark concludes that ordinary government expenses cannot be recovered as compensation, arguing that damages exceeding actual damages should be considered punitive in public law just as they are in private law. ${ }^{194}$ In Calero-Toledo, as we have seen, punitive measures cannot be supported. Recovery of any actual damages presumably would be based on some kind of tort theory. But no theory of tort liability would allow the government compensation as claimed in Calero-Toledo. Pearson Yacht Leasing Company was not shown to have been negligent. Nor can the element of exceptional danger necessary to strict liability be found in Pearson's ordinary leasing of yachts. On either theory of liability, Pearson cannot be shown to have been the legal cause of damage suffered by the government. Nor can the value of the yacht be shown to relate to the damages suffered. The difficulties present in Calero-Toledo are not unusual; they are apt to arise in any compensatory forfeiture suit. Thus, although a forfeiture might theoretically be upheld as a compensatory measure, it is unlikely that in practice any such scheme could ever be satisfactory.

In conclusion, while in Calero-Toledo the Supreme Court raised valid reasons to support some forfeitures, the Court failed to justify ordering the forfeiture in the case before it. The Court should reconsider its decision. It should begin a restructuring of American forfeiture law based upon analysis of each individual forfeiture against the rationale raised to support it. The Court should recognize, as its German counterpart did a quarter century ago, that forfeiture can be justified in a constitutional state only if based upon the culpable conduct of the owner or upon a real danger to the community.

193. 416 U.S. at 687 n. 26.

194. Clark, supra n. 176 , at $469-75$. 